\title{
PECULIARITIES OF EMOTIONAL INTELLIGENCE OF DEVIANT ADOLESCENTS
}

УДК 159.922.8:616.8(045)

DOI https://doi.org/10.32843/2663-

5208.2020.12-1.29

\section{Євдокімова О.О.}

д.психол.н., професор, завідувач касредри соціології та психології

Харківський національний університет внутрішніх справ

Приймаченко О.М.

старший викладач кафедри

правоохоронної діяльності

та кримінально-правових дисциплін

Університет митної справи та фінансів у статті подано стислий огляд наявних зарубіжних і вітчизняних досліджень із проблеми емоційного інтелекту, надано інтерпретації його основного змісту, структури, визначення фрункцій у дорослому віковому та підлітковому періодах. Здійснено теоретичний аналіз наукових робіт, присвячених виявленню позитивних $і$ негативних зв'язків здібностей емоційного інтелекту з проявами девіантності в дітей підліткового віку. Особлива увага приділена висвітленню суперечливих даних різних авторів щодо зв'язку окремих складників емоційного інтелекту з агресивною поведінкою, залученням до булінгу, кібербулінгу, з маніпулюванням емоціями інших, із вирішенням міжособистісних консрліктів. Проаналізовано результати пілотного дослідження особливостей проявів емоційного інтелекту в підлітків, схильних до девіантної поведінки, і підлітків із нормативною поведінкою. у дослідженні запропоновано використовувати ієрархічну модель емоційного інтелекту авторів-розробників концепції емоційного інтелекту (Мейера-Селовея-Карузо) - «Модель здібностей». Перевірено припущення, якщо людина схильна до девіантної поведінки, то El сприяє реалізації такої поведінки, навпаки, знижує можливість, якщо людина не схильна до неї. Діагностування емоційного інтелекту здійснювалося з використанням тесту Дж. Мейера, П. Селовея, Д. Карузо «Емоційний інтелект» (MSCEIT v. 2.0) і методики Self Report Emotional Intelligence Test (SREIT) (Schutte et al., 1998; у перекладі Садокової, 2001). Схильність до девіантної поведінки перевірено із застосуванням методики «Схильність до поведінки, що відхиляється від нормативної) СВП А. Орла. На підставі отриманих результатів запропоновано вважати че припущення недостатньо коректним, адже розвиток емоційного інтелекту, навпаки, може стримувати в поведінці схильність до девіантності. У пілотному дослідженні встановлено, що девіантні підлітки й підлітки з поведінкою, схильною до девіантної, відрізняються низькими показниками EI порівняно зі своїми однолітками, поведінка яких характеризується показниками норми.

Ключові слова: емоційний інтелект, «Модель здібностей», девіантні підлітки, підлітки, схильні до девіантної поведінки, підлітки з нормативною поведінкою.

The article presents a brief overview of existing foreign and domestic research on the problem of emotional intelligence, interpretation of its main content, structure, definition of functions in adulthood and adolescence. Theoretical analysis of scientific works devoted to determining the positive and negative connections between emotional intelligence abilities and manifestation of deviance in adolescents has been carried out. Peculiar attention is paid to contradictory data of different authors regarding the individual emotional intelligence abilities with aggressive behavior, involvement in bulling, cyber-bulling, manipulation of emotions of others, and solving interpersonal conflicts. The results of a search study on determining the peculiarities of emotional intelligence in deviant adolescents, adolescents inclined to deviant behavior and adolescents with normative behavior are analyzed. It is proposed to use in the research the hierarchical model of emotional intelligence of the authors-developers of the concept of emotional intelligence (Mayer-Salovey-Caruso) - "The Ability Model". In the study it was tested the assumption that if a person is inclined to deviant behavior, then $E I$ facilitates the implementation of such behavior and, on the contrary, reduces the possibility if the person is not inclined to it. Testing of emotional intelligence has been carried out using the J. Mayer, P. Salovey, D. Caruso "Emotional Intelligence" test (MSCEIT $\vee$ 2.0) and the Self Report Emotional Intelligence Test (SREIT) (Schutte et al., 1998, translated by Sadokova, 2001). The inclination to deviant behavior was tested using the method of IDB (Inclination to Deviant Behavior) by A. M. Orel. Based on the obtained results, it is suggested that assumption that has been tested is not correct enough, as the development of emotional intelligence, on the contrary, may reduce the tendency to deviance. In the research experiment it is found that deviant adolescents and adolescents inclined to deviant behavior have low EI scores compared to their peers, whose behavior is characterized as normative.

Key words: emotional intelligence, The Ability Model of Emotional Intelligence, deviant adolescents, adolescents, inclined to deviant behavior, adolescents with normative behavior.
Постановка проблеми. Проблеми зв'язку та взаємодії розуму й почуттів, раціонального й емоційного викликали глибоку зацікавленість науковців із давніх часів. Упродовж останніх 30 років ця проблема досліджується як феномен «емоційний інтелект» (далі - ЕІ).

Аналіз останніх досліджень і публікацій. За цей час накопичилося чимало теорій і моделей щодо інтерпретації його основного змісту та структури. Згідно з визначенням Дж. Мейера й П. Селовея, засновників концепції цього феномена, емоційним інтелек- том $€$ один із основних видів інтелекту, який представлений здібностями до ідентифікації й вираження емоцій, регуляції власних емоцій, до управління своїм мисленням і поведінкою $[10 ; 11]$. Крім моделі здібностей, у теорії EI зарубіжні психологи виокремлюють моделі «рис» [14] і сукупності стійких рис особистості, соціальних, емоційних і когнітивних навичок і мотивації [15].

Вітчизняні та зарубіжні дослідники здійснили вагомий внесок у розуміння змісту ЕІ, його структури, функцій, гендерних особливостей, 
міжособистісних стосунків, можливості розвитку, дослідили його ресурсну властивість у подоланні синдрому вигорання, розширили діагностичний інструментарій його вивчення (Е. Носенко, Н. Коврига, С. Дерев'янко, О. Власова, Т. Солодкова, Д. Люсін, І. Андрєєва). Експериментально доведено вплив El на успішність життєдіяльності особистості (Е. Носенко, А. Четверик-Бурчак); виявлено відмінності в структурі El щодо прояву його як здібності або як риси в поведінковому аспекті в контексті різних соціальних ситуацій; виокремлено та охарактеризовано його індивідуально-особистісні типи, види й підтипи, визначено взаємозв'язок зі спеціальністю, статусом індивіда, конкретизовано особливості структури в працівників соціономічних професій (Л. Камишнікова, І. Андрєєва, О. Милославська, О. Амплєєва, Ю. Бреус).

Особливо «емоційно-насиченим» віковим періодом науковцями вважається підлітковий, у зв'язку з чим проблема виявлення особливостей і розвитку ЕІ підлітків посіла одне з провідних місць у психології за останні часи. Дослідженням ЕІ дітей і підлітків наукові інтереси присвятили Ю. Давидова, І. Андрєєва, А. Александрова, І. Опанасюк, М. Шпак та ін. Дослідники виявили сутнісні ознаки й особливості структури ЕІ в підлітковому та дитячому віці, проаналізували його статеві й гендерні особливості.

Емоційні порушення, що виникають в окремих підлітків, мають свої наслідки: порушення поведінки, шкільна неуспішність, ускладнення в спілкуванні з однолітками й дорослими тощо. Відкриття свого внутрішнього світу підлітком супроводжується радістю та хвилюванням, але при цьому викликає тривожні хвилювання. Разом з усвідомленням своєї унікальності радість заміщується почуттям самотності. Підліткове «я» часто відчувається як стурбованість і відчуття внутрішньої пустоти, яку хочеться чим-небудь заповнити. Підлітку складно опрацьовувати власні емоції. У більшості випадків він не розуміє, що з ним відбувається, що він почуває та як із цим поводитися. Усі ці проблеми лежать в основі формування поведінки, що відхиляється [2, с. 247].

Вивчення El підлітків з ознаками девіантної поведінки також не залишається поза увагою вчених. Так, натепер виявлено розбіжності прояву El девіантних і недевіантних підлітків (О. Пасмор); проаналізовано зв'язок Еl з особливостями соціально-психологічної адаптації (А. Дегтярьов); установлено особливості Еl підлітків, схильних до інтернет-залежності (В. Густодимова).

Окремі науковці в процесі досліджень отримують суперечливі результати. Так, наприклад, Е. Гарсія-Санчо з колегами проаналізували вже наявні дослідження, що стосуються вивчення зв'язку El й агресивної поведінки. У більшості досліджень виявлено негативний зв'язок ЕІ з агресією різних форм: агресивним гумором, фізичною агресією, зловживанням стосовно інших людей. Водночас інші дослідження не виявили негативні кореляції ЕІ з вербальною агресією та сексуальним насильством. Суперечливі результати автори пояснили кількома обставинами: методами, які діагностують ЕІ як риси та як здібності; функцією El як модератора зв'язку макіавеллізму й агресії; особливістю вибірок зазначених досліджень, які складалися переважно з дорослих людей. Загалом аналіз показав необхідність проведення лонгітюдного дослідження на вибірці підлітків для розуміння механізмів зв'язку емоційного інтелекту й агресії в підлітків і її зміни з часом [8].

Отже, з метою формування чіткого розуміння, які саме складники ЕІ варто й доречно розвивати, щоб не ускладнити прояви девіантної поведінки, достатньо актуальним натепер $€$ завдання здійснення більш глибокого теоретичного аналізу вже наявних досліджень і внесення доповнень новими емпіричними даними.

Постановказавдання. Метастатті-подати стислий огляд наявних зарубіжних і вітчизняних досліджень із проблеми емоційного інтелекту, надати інтерпретації його основного змісту, структури, визначення функцій у дорослому віковому та підлітковому періодах.

Виклад основного матеріалу дослідження. Вагомий внесок у дослідження зв'язку ЕІ з так званою «нерозумною» поведінкою (термін Дж. Мейера, Д.Р. Карузо, П. Селовея [10]) здійснили зарубіжні вчені. Крім установлення зв'язку Еl з девіантною поведінкою, зарубіжними авторами проаналізована взаємодія зазначених конструктів з особистісними рисами; цікавими є висновки у визначенні впливу El під час вирішення міжособистісних конфліктів. Зупинимося детальніше на результатах цих досліджень.

Почнемо з проблеми булінгу, яка останніми роками стала надзвичайно актуальною для закладів освіти більшості країн. Низка досліджень у цьому напрямі присвячена булінгу та кібербулінгу з акцентом на вивчення впливу рівня El на залученість підлітків до булінгу і сприйняття ними булінгу. Так, установлено, що прогнозування ймовірної реакції об'єкта булінгу потребує від суб'єкта високого рівня емоційного інтелекту, функція останнього зводиться до підтримки стосунків із бажаними членами групи, які можуть брати участь у «нерозумній» поведінці. Високий рівень емоційного інтелекту може проявлятися в маніпулюванні емоціями інших людей під час взаємодії з іншими заради підтримки суб'єктом власного соціального статусу (А. Бекон, Л. Ріган [6]). 
П. Еліп із колегами довели, що залучення до булінгу співвіднесено з такими здібностями булера: підвищеною увагою до емоцій і низькою регуляцією емоцій. Жертви булінгу характеризуються низькою ясністю й точністю в розумінні емоцій і високою увагою до емоцій [13]. У ракурсі дослідження кібервіктимізації виявлено, що в жертв кібербулінгу низькі здібності до розуміння й регуляції емоцій, а високий рівень уваги до емоцій має позитивну кореляцію з такими емоціями, як зневіра й роздратування [13].

І. Зух із колегами виявили, що емоційне сприйняття й експресія емоцій у кіберпросторі є двома різними факторами [16]. В інтернеті людина може чудово розуміти емоції іншої людини, при цьому не виражаючи свої власні, і навпаки. Це свідчить про відмінність спілкування в кіберпросторі й реальному житті, де необхідно реагувати на емоції іншої людини та виражати власні, щоб відбувалася взаємодія [16].

У.К. Наглер із колегами вивчали зв'язок El й маніпулювання емоціями іншої людини, припускаючи, що модератором цього зв'язку може бути темна тріада: макіавелізм, нарцисизм і психопатія. Виявилося, що нарцисизм і психопатія сприяють використанню високого Еl для маніпулювання емоціями інших [9]. Крім цього, ураховуються мета суб'єкта й емоції мішені, які можуть мати як позитивну валентність, так і негативну.

На думку І. Беркович та О. Ейял, до різновидів маніпулювання емоціями можна зарахувати приховування інформації, дезінформацію, апеляцію до емоцій мішені з метою мотивування для виконання будь-якого завдання, а також маніпулювання 3 метою пов'язати виконання завдання 3 емоційною привабливістю [7].

Наступний напрям досліджень емоційного інтелекту - міжособистісні конфлікти. Згідно з результатами К. Меллер і К. Квантес, уподобання у вирішенні конфліктів визначали реальну поведінку навіть у тому випадку, якщо вона не була соціально бажаною; ті, хто вважає конфронтацію й приниження іншої людини доречними стратегіями в конфлікті, більш схильні до такої поведінки в реальності, якщо в них висока здатність усвідомлювати власні емоції й керувати ними; для тих, хто вважає, що маніпуляції або вербальна агресія є доречними стратегіями для вирішення конфліктів, компонент ЕІ як здібність використання емоцій стає самостійним елементом у реалізації цих стратегій у реальній поведінці [12].

Отже, результати низки досліджень, про які йшлося вище, формують припущення, якщо людина схильна до девіантної поведінки, то El сприяє реалізації такої поведінки, навпаки, знижує можливість, якщо людина не схильна до неї. 3 метою з'ясування коректності цього припущення проведено пілотне дослідження.

В основу пропонованого дослідження покладена ієрархічна модель ЕІ авторів-розробників концепції ЕІ (Мейера-Селовея-Карузо), яка отримала назву «Моделі здібностей» [3; 10]. За цією моделлю, до складу El входять чотири типи здібностей: 1) сприйняття емоцій здібність розпізнавати як емоції інших людей, так і власні емоції; 2) використання емоцій для стимуляції мислення - здібність активізувати свій мисленнєвий процес, використовуючи емоції як фактор мотивації; 3) розуміння емоцій - здібність визначати причину появи емоції, розпізнавати зв'язок між думками та емоціями, визначати зміну емоцій, інтерпретувати емоції, розуміти складні, амбівалентні почуття; 4) управління емоціями - здібність використовувати власні емоції та емоції інших людей для досягнення поставлених цілей [3].

У дослідженні взяли участь 190 дітей підліткового віку: підлітки, які перебували в приймальнику-розподільнику для дітей Дніпровського відділення поліції ГУНП в Дніпропетровській області й учні загальноосвітніх шкіл м. Дніпра (№ 61, № 67) і Дніпропетровської області (Новоолександрівська ЗОШ, Сурсько-Литовська ЗОШ).

Дослідження здійснювалося в декілька етапів. На першому етапі за допомогою методики СВП А. Орла ми діагностували респондентів на схильність до поведінки, що відхиляється від нормативної (нормативна поведінка (нормальна, «стандартна») відповідає соціальним нормам, характерна для більшості людей, викликає схвалення оточуючих і приводить до нормальної адаптації [1]).

У результаті ми виокремили три групи підлітків. До першої групи ввійшли 29 підлітків, які перебували в приймальнику-розподільнику для дітей Дніпровського відділення поліції ГУНП в Дніпропетровській області. За результатами методики СВП, ці підлітки отримали високі бали за всіма шкалами методики, а саме: 1. «Схильність до подолання норм і правил». 2. «Схильність до адиктивної поведінки». 3. «Схильність до аутоагресії». 4. «Схильність до агресії та насильства». 5. «Вольовий контроль емоційних реакцій» (зворотна шкала). 6. «Схильність до делінквентної поведінки». Цю групу ми умовно назвали «Девіантні підлітки».

Другу групу становили 76 підлітків загальноосвітніх шкіл, які мали також високі бали за вказаними шкалами, отже, показали певну схильність до девіантної поведінки. Цю групу ми умовно назвали «Підлітки, схильні до девіантної поведінки»

На підставі t-критерію для незалежних вибірок за такими шкалами «Схильність до подолання норм і правил» (t-знач. $=0,4252$ при $\mathrm{p}=0,671460)$, «Схильність 
до агресії та насильства» (t-знач. $=-1,6067$ при $p=0,110750)$ i «Вольовий контроль емоційних реакцій» $(\mathrm{t}-3 н а ч . ~=-1,3089$ при $\mathrm{p}=0,193059)$ між першою та другою групами не виявлено значущих розбіжностей.

До складу третьої групи ввійшли 85 підлітків, у яких показники за методикою СВП були в межах норми й при цьому за всіма шкалами спостерігалися значущі відмінності з першою та другою групами. Умовна назва групи «Підлітки з нормативною поведінкою».

На другому етапі дослідження в трьох групах проведені методики El: тест Дж. Мейера, П. Селовея, Д. Карузо «Емоційний інтелект» (MSCEIT v. 2.0) [4] і методика Self Report Emotional Intelligence Test (SREIT), створена Н. Шутте з колегами на базі ранньої моделі Дж. Мейера й П. Саловея (Schutte et al., 1998; уперекладі Садокової, 2001) [4].

На рис. 1 і рис. 2 відображені результати, отримані за методиками SREIT і MSEIT відповідно. На їх підставі можна зробити припущення, що в девіантних підлітків, які відрізняються високими результатами за методикою СВП, показники емоційного інтелекту $є$ набагато нижчими, ніж в однолітків. Правильність цього припущення доведена статистичним

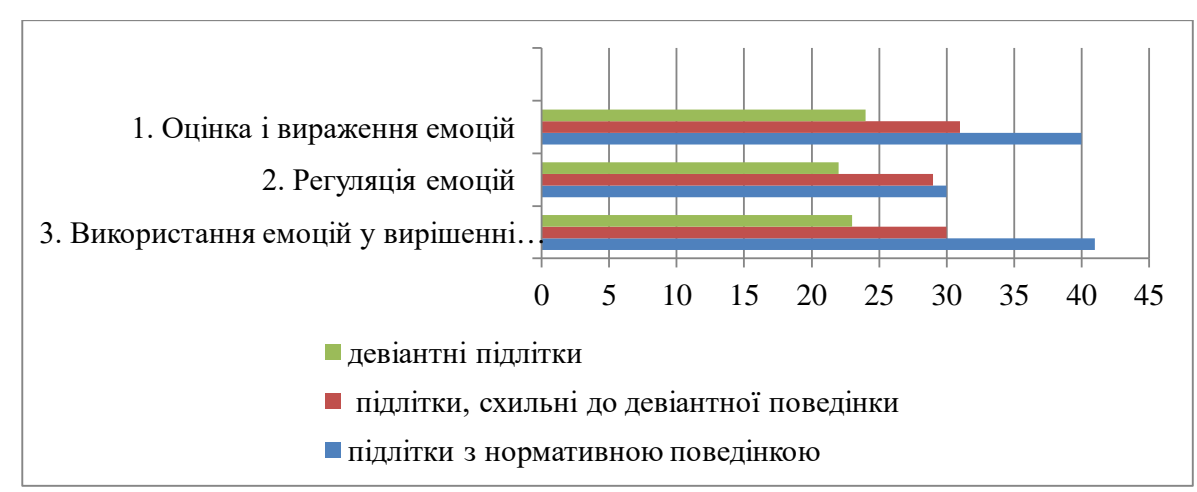

Рис. 1. Середні показники за результатами методики SREIT

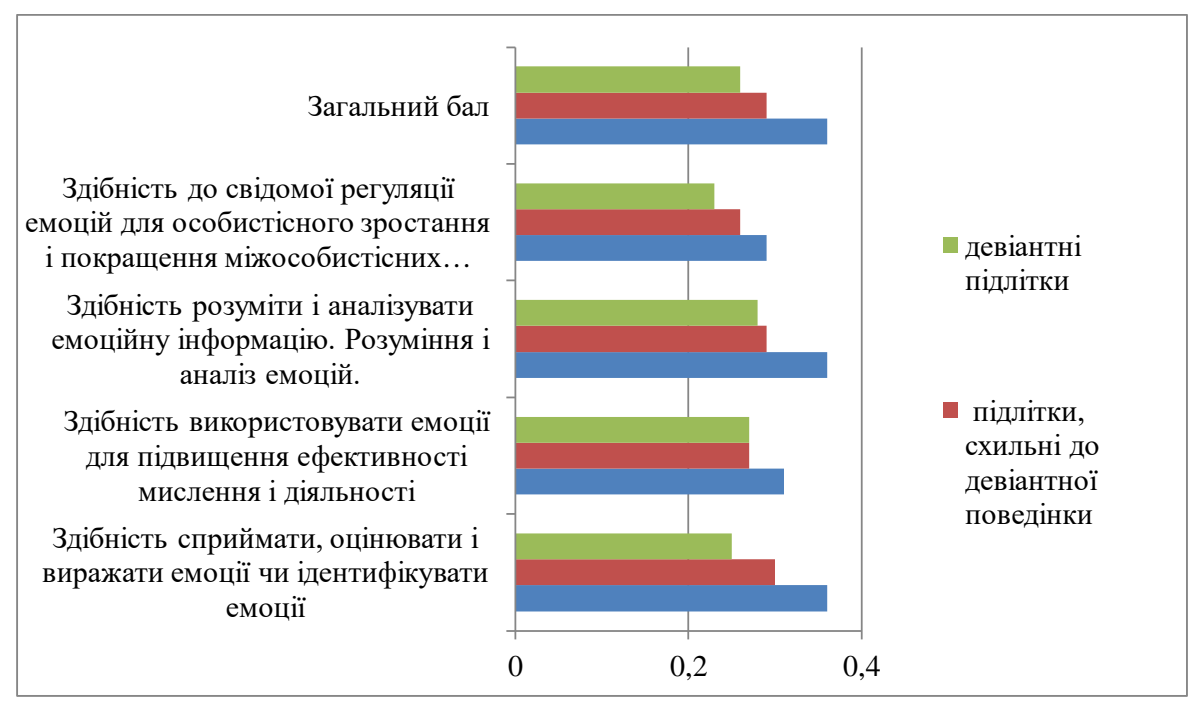

Рис. 2. Середні показники за результатами методики MSCEIT аналізом за допомогою t-критерію для незалежних вибірок, за результатами якого видно, що перша група девіантних підлітків за всіма шкалами методики SREIT відрізняється від решти груп однолітків і що існують розбіжності за всіма шкалами методики MSEIT порівняно з третьою групою.

У другій групі підлітків, схильних до девіантної поведінки, за результатами методики SREIT спостерігаються значущі розбіжності порівняно з третьою групою підлітків із результатами в межах норми за методикою СВП із загальноосвітніх шкіл за всіма шкалами, окрім результатів за шкалою «Регуляція емоцій»; за результатами методики MSCEIT за всіма п'ятьма шкалами існують значущі розбіжності порівняно з третьою групою, у якої показники в межах норми. Відсутність значущих розбіжностей за шкалою «Регуляція емоцій» методики SREIT можна пояснити так: оскільки ця методика $є$ опитувальником у формі самозвіту, то, імовірно, він є менш чутливим у діагностичному плані порівняно з тестом MSCEIT, який містить проективні блоки, кейсові завдання й опитувальну частину.

Отже, видно, що девіантні підлітки й підлітки $з$ поведінкою, схильною до девіантної, відрізняються низькими показниками El порівняно зі своїми однолітками, поведінка яких характеризується показниками норми за методикою СВП.

Висновки 3 проведеного дослідження. На підставі результатів представленого пілотного дослідження можна резюмувати таке:

1. Установлено, що розвиток ЕІ в девіантних підлітків і підлітків, схильних до девіантної поведінки, знаходиться на певному рівні, суттєво нижчому порівняно з розвитком ЕІ підлітків із нормативною поведінкою, про що свідчить різниця показників між групами за всіма шкалами методик SREIT і MSCEIT.

2. Рівень розвитку ЕI девіантних підлітків і підлітків, схильних до девіантної поведінки, також різниться між собою. Девіантні підлітки показали нижчі результати розвитку El порівняно зі 
своїми однолітками, схильними до девіантної поведінки, в обох методиках, за винятком двох шкал методики MSCEIT: «Здібність використовувати емоції для підвищення ефективності мислення й діяльності», за якою результати обох груп повністю збіглися, і «Здібність розуміти й аналізувати емоційну інформацію. Розуміння й аналіз емоцій», за якою результати обох груп відрізняються не суттєво.

Отримані результати ставлять під сумнів припущення, зроблене на підставі попередніх зарубіжних досліджень, що коли людина $€$ схильною до девіантної поведінки, то Еl сприяє реалізації такої поведінки, навпаки, знижує можливість, якщо людина не схильна до неї, адже результати здійсненого дослідження актуалізують ще одне припущення: розвиток El може піддавати інгібіції схильність до девіантності, оскільки, як видно на рис. 1 і 2, чим вищий рівень ЕІ, тим нижча виражена девіантність або не виражена взагалі (у групі підлітків, результати яких за методикою СВП виявилися в межах норми, а El виявився найвищим).

Отже, результати представленого пілотного дослідження не дають змоги вважати припущення, що коли людина $є$ схильною до девіантної поведінки, то ЕІ сприяє реалізації такої поведінки, навпаки, знижує можливість, якщо людина не схильна до неї, однозначно коректним, а отже, потребує більш глибокого вивчення й уточнення, що може бути перспективою подальшого дослідження. Крім того, вивчення особливостей емоційного інтелекту девіантних підлітків дасть змогу краще зрозуміти й створити передумови для мінімізації дезадаптивних форм поведінки підлітків, схильних до девіантної поведінки, і використовувати отримані дані для профілактики дезадаптації підростаючого покоління загалом.

\section{ЛІТЕРАТУРА:}

1. Вольнова Л.М. Профрілактика девіантної поведінки підлітків : навчально-методичний посібник до спецкурсу «Психологія девіацій» для студентів спеціальності «Соціальна робота»: у 2 ч. 2-ге вид., перероб і доповн. Київ, 2016. Ч. 1 : Теоретична частина. 188 с.

2. Дегтярёв А.В. Конструирование тренинговых программ по развитию эмоционального интеллекта у подростков с отклоняющимся поведением. Психологическая наука и образование. 2013. № 3. С. 244-253.
3. Ракітянська Л. Сутність та зміст поняття «емоційний інтелект». The pedagogical process: theory and practice. Series "Pedagogy". 2018. № 4 (63). C. 35-42.

4. Садокова А.В., Воронкина П.М. Методика исследования эмоционального интеллекта подростков. Психологическая диагностика : ежеквартальный научно-методический и практический журнал / ред. М.К. Акимова, В.Г. Колесников. 2006. № 3. С. 68-84.

5. Сергиенко Е.А., Ветрова И.И. Тест Дж. Мэйера, П. Сэловея, Д. Карузо «Эмоциональный интеллект» (MSCEIT v. 2.0) : руководство. Москва : Институт психологии РАН, 2010. 176 с.

6. Bacon A.M., Regan L. Manipulative relational behaviour and delinquency: sex differences and links with emotional intelligence. The Journal of Forensic Psychiatry \& Psychology. 2016. Vol. 27. № 3. P. 331-348.

7. Berkovich I., Eyal O. Good cop, bad cop: Exploring school principals' emotionally manipulative behaviours. Educational Management Administration \& Leadership. 2017. Vol. 45. № 6. P. 44-58.

8. Garcia-Sancho E., Salguero J.M., FernandezBerrocal P. Ability emotional intelligence and its relation to aggression across time and age groups. Scandinavian Journal of Psychology. 2017. Vol. 58. № 1. P. 43-51.

9. Is there a "dark intelligence"? Emotional intelligence is used by dark personalities to emotionally manipulate others / U.K.J. Nagler et al. Personality and Individual Differences. 2014. Vol. 65. P. 47-52.

10. Mayer J.D., Caruso D.R., Salovey P. The Ability Model of Emotional Intelligence: Principles and Updates. Emotion Review. Vol. 8. № 4. P. 290-300.

11. Mayer J.D., Di Paolo M., Salovey P. Perceiving affective content in ambiguous visual stimuli:Acomponent of emotional intelligence. J Pers. Assessment. 1990. V. 54. № 3, 4. P. 772-781.

12. Moeller C., Kwantes C.T. Too Much of a Good Thing? Emotional Intelligence and Interpersonal Conflict Behaviors. The Journal of Social Psychology. 2015. Vol. 155. № 4. P. 314-324.

13. Perceived emotional intelligence and involvement in several kinds of school bullying / P. Elipe et al. Behavioral Psychology. 2012. Vol. 20. № 1. P. 169-181.

14. Petrides K.V., Pita R., Kokkinaki F. The location of trait emotional intelligence in personality factor space. British Journal of Psychology. 2007. Vol. 98. № 2. P. 273-289.

15. The development of emotional intelligence in adolescence / I. Esnaola et al. Anales de psicología. 2017. Vol. 33. № 2. P. 327-333.

16. Zych I., Ortega-Ruiz R., Marin-Lopez I. Emotional content in cyberspace: Development and validation of E-motions Questionnaire in adolescents and young people. Psicothema. 2017. Vol. 29. № 4. P. 563-569. 